\title{
FINANCIAL MANAGEMENT OF MICRO, SMALL, AND MEDIUM ENTERPRISES IN CEBU, PHILIPPINES
}

\author{
Jose Marie M. Anoos \\ https://orcid.org/0000-0002-7510-6315 \\ josemarieanoos@gmail.com \\ Cebu Technological University \\ Judy Ann O. Ferrater-Gimena \\ ORCID No. 0000-001-5352-8253 \\ judygimena@gmail.com \\ University of Cebu \\ Jonathan O. Etcuban \\ https://orcid.org/0000-0001-8930-6476 \\ joetcuban@gmail.com \\ Cebu Technological University
}

\author{
Aahron M. Dinauanao \\ https://orcid.org/0000-0002-1183-1331 \\ dinauanao@gmail.com \\ University of Southern Philippines Foundation
}

\section{Philip Joel D.R. Macugay}

https://orcid.org/0000-0003-4664-2335

drjoelmacugay@gmail.com

University of Southern Philippines Foundation

\section{Lolita V. Velita}

https://orcid.org/0000-0001-8784-4297

lolita.velita@ctu.edu.ph

Cebu Technological University

\begin{abstract}
The Micro, Small, and Medium Enterprises (MSMEs) play a significant role in developing the Philippine economy by reducing poverty and creating jobs for the country's growing labor force. This study aimed to unveil the financial management practices and challenges confronting the MSMEs in Danao City, Philippines. This research applied the descriptive correlational research method and conducted among the MSMEs that are operating in Danao City, Cebu. The respondents were the 354 owners and employees of MSMEs. They are chosen using the cluster-sampling technique. This investigation further utilized a researcher-made survey tool to gather vital information on the profile, financial management practices, and challenges faced by the MSMEs. Frequency, simple percentage, weighted mean, Chi-square test of independence, and ANOVA were used to treat the gathered data. The study revealed that the financial management system was moderately practiced. It was concluded that the MSMEs management does not practice the generally accepted standards on the financial management and control of the business, which poses some threats on its sustainability considering that their predominant size, the volume of assets, and revenue earned is low. The researchers strongly recommend that the local government officials enact city ordinance on the vital role of MSMEs in complying with the governmental regulations to improve business transactions in regional offices use the proposed position paper.
\end{abstract}

KEYWORDS: Financial management, MSMEs, descriptive study, Philippines 


\section{INTRODUCTION}

MSMEs had a pivotal job in building up the Philippine economy. They help decrease destitution by making employments for the nation's developing work power. They animate financial improvement in-country and distant. They fill in as essential accomplices to enormous undertakings as providers and suppliers of help administrations. They fill in as a reproducing ground for new business people and huge companies. A lively MSME part means that a flourishing and developing economy. Despite arrangements that intend to give an empowering situation to MSME advancement, the industry still faces different limitations that keep it from understanding its full development and potential.

There is a broad understanding that MSMEs are imperative to accomplishing respectable and profitable work as they all-around record for $66 \%$ everything being equal and make most of the new posts. Along these lines, the advancement of SMEs has been a primary region of intercession for the International Labor Organization (ILO). Its warning administrations on SME strategies are in intense interest among ILO part nations (Hughes \& Haworth, 2013).

Starting in 2010, there was an aggregate of 777,687 business ventures in the Philippines (Khor et al., 2013). Of this figure, MSMEs spoke to 99.6 percent with 774,664 foundations, while enormous endeavors spoke to 0.4 percent with 3,023 foundations (Lanzona, 2015; De Vera, 2012). Smaller-scale endeavors contained 91.6 percent $(709,899)$ of the absolute number of MSMEs, while little and medium ventures represented 8 percent $(61,979)$ and 0.4 percent $(2,786)$, individually (Cheng \& Rabena, 2017).

MSMEs are viewed as essential for a nation's commercial development, work creation, and advancement. Their absence of access to financing has regularly cited as one of the significant constraints affecting their performance and competitiveness. The lack of access to funding implies that a substantial number of SMEs cannot obtain financing from banks and other sources to start, innovate, grow, and develop their enterprises (Aldaba, 2010).

Small businesses do not share the same financial management problems with large companies. Then again, the absence of access to financing has been distinguished as the strictest requirement for MSME development and improvement. As per Cassar (2004), funding, especially from outside sources, for example, banks, turns out to be increasingly necessary as firms begin growing. Although assets have been made accessible by government budgetary organizations and private banks, most MSMEs still have difficulty accessing these funds because of: insufficient collateral, limited credit histories and banking relationships; inadequate financial records and business plans; and high-interest rates. MSMEs would tend to rely on informal non- banking channels for financing support.

Financial education needs deciding how others are influenced when an individual settles on a budgetary choice (Buchanan, 2014; Kirman, 2010). It is an aggregate issue 
of the entire country as it directly affects a younger age (Hastings et al., 2013; Lusardi et al., 2010). It is significant for the country to make arrangements on the best way to execute the idea of money related education in an ideal way.

Money related proficiency needs deciding how others are influenced when an individual settles on a monetary choice. In developing nations, the high level of the populace is monetarily unskilled and outside money related part. In this examination, it discovered that the utilization of proportions in money related investigation of the organization was just $36 \%$ on productivity, $43 \%$ on obligation, $38 \%$ for viability, and $62 \%$ for liquidity wherein shockingly this is a little rate (Plakalović, 2015). Nunoo and Andoh (2011) undertook a study in Ghana, which reveals that there was insufficient financial literacy amongst small and middle entrepreneurs because of which $44 \%$ of them did not have access to financial services. More financially literate entrepreneurs would probably make use of financial services, and consequently, financial education would have a positive connection with the usage of financial services.

Due to the prevailing problems on the low financial literacy among the people, especially the small entrepreneurs in many developing countries and in consonance with the Millennium Development Goals on eradicating poverty, there is a need to undertake this study among the MSMEs with the end view of improving the socioeconomic standard among the owners and employees with the growth of MSMEs, wherein a vast number of people have benefited, either through profits gained from entrepreneurship, or salaries and wages from employment. Since the management of business monetary resources is very critical in the case of SMEs or MSMEs. It is vital that a study on financial management applied by the owners is needed. The various challenges confronting them in their quest for survival in the market have to be conducted.

\section{LITERATURE REVIEW}

The Financial Management Theory states that the way a manager makes decisions results in either the success or failure of any organization (Brigham \& Ehrhardt, 2013). According to Stern et al. (1995), it is a popular tool that is used for building reliable and effective financial decisions regarding the business. It deals with the usage of money in a company, including all acquisitions, sales, and expenditure. This assists the businessman and provides tools when putting into practice and will help one achieve the financial goals of the organization. Money related administration hypothesis is not generally so natural to pursue because monetary administration depends on some various angles (Glick et al., 2006; Belke \& Gros, 2002): securing and designation of assets, redistributing, streamlining creation codes, chance administration, venture thoughts, the pace of premium, and Return On Investment (ROI).

There are bunches of procedures to manage in a single monetary issue for any business. Once in awhile, such techniques become exceptionally hard to pursue, mainly when the user requires change inside the business framework and structure, and nobody preferences change. There have been loads of revisions that have been made to conventional budgetary administration hypothesis throughout the latest couple of years, 
and pros have made it increasingly viable and differing to help entrepreneurs. The most critical favorable position of utilizing money related administration hypothesis is that it has a progressively shifted strategy and devices, with which an entrepreneur can use to expand its benefit, through after forceful methodologies in speculation and cost control. The theory will allow the owner to gain advantage from some unexpected sources, which is the most significant benefit of using it.

Moreover, almost everything that a human being does involves decisions. Therefore, to theorize about choices is nearly the same as speculating about human activities. Nonetheless, Decision Theory is not precisely as comprehensive as that. It centers around just a few parts of social business. Specifically, it focuses on how an individual uses one's opportunity. A person's decisions, in these circumstances, are coordinated physical exercises. Consequently, the choice hypothesis is worried about objective organized conduct within sight of choices.

An authoritative framework is, just how an organization is set up. A practical hierarchical structure spreads out both a chain of importance and the progression of correspondence in an organization. It is fundamental for each business, regardless of its size, to actualize an authoritative framework. There are many benefits to having a welldefined organizational structure, including improved efficiency, productivity, and decision-making. Each structure has its strengths and weaknesses. Ultimately, these pros and cons depending on the type of business you run, your industry, the size of your organization, and other factors. It is essential to consider every kind of organizational system before deciding which is right for your company.

Financial administration additionally alluded to as administrative account, corporate money, and business money, which is an essential leadership procedure worried about arranging, securing, and using assets in a way that accomplishes the association's ideal objectives. It is depicted as the procedure for and the examination of settling on money related choices in the business setting. Budgetary administration is a piece of a more extensive control considered the money that is an assortment of certainties, standards, and speculations identifying with raising and utilizing the cash by individuals, businesses, and governments. This concerns both financial management of profitoriented business organizations, particularly the corporate form of marketing, as well as concepts and techniques that apply to individuals and the governments.

The main component of this study was to assess the financial management practices of owners of the MSMEs. These are the critical aspects of the business entity since it involves the process of planning and monitoring the financial resources of the firms. Kimunguyi et al. (2015) further argued that good budget management practices positively influenced budgetary execution and suggested improvement and usage of supportable strategies and guidelines for spending the board. As indicated by Warue and Wanjira (2013), the absence of planning and money related control lead to lackluster showing. They further contended that on the off chance, those laborers are associated with the planning procedure. At that point, the general execution increments. While spending interest includes unmistakably as profoundly affecting execution, 
International Journal of Small Business and Entrepreneurship Research

Vol.8, No.1, pp.53-76, January 2020

Published by ECRTD-UK

Print ISSN: 2053-5821(Print), Online ISSN: 2053-583X (Online)

different factors, for example, culture may debilitate spending support and still outcome in an incredible performance.

The accomplishment of an endeavor relies upon its capacity to give administrations to clients or clients and remain monetarily reasonable. For an association that provisions merchandise to its clients, the essential movement is to have appropriate items accessible at a reasonable cost inside a sensible timescale. Numerous pieces of a business are engaged with setting up this circumstance. At first, it is the advertising and structure offices, at that point, obtaining and, now and again, the producer is locked in. Currently, the commercial center principle movement is giving congruity of supply to clients. Stock control is the movement that sorts out the accessibility of things to clients. It facilitates obtaining, assembling, and conveyance capacities to address showcasing issues. This job incorporates the supply of mainstream deals, things, new items, consumables, save parts, old ideas, and every single other amount. Stock empowers an organization to help the client administration, coordination, or assembling exercises in circumstances where buy or production of the items cannot fulfill the interest. It could emerge either in light of the speed of obtaining, or because assembling is excessively extended, or because the amounts requested cannot be given without stocks.

As a small business owner, one should know that implementing properly designed controls with limited resources might be challenging. However, not addressing deficiencies can expose the business to operational and financial risks and losses. Fortunately, there are steps that the owner can take to help prevent and detect fraud in the company. The most widely recognized kinds of inside control shortcomings distinguished in private companies could frequently be alleviated through actualizing a blend of against misrepresentation controls and marginally altering existing procedures. The accompanying five inward control difficulties are probably the most usually found in private ventures: partition of obligations, arrangements and methods, documentation, oversight and survey, and client access rights for data frameworks.

The effectiveness of market rivalry as a system for designating merchandise and ventures is the most part acknowledged statute (Baack \& Harris, 2013; Ross \& Szymanski, 2010). The State perceives that measures that defend aggressive conditions should fortify past standards embraced to change primary divisions in the economy. The State additionally recognizes that the arrangement of equal chances to all advances the innovative soul supports private ventures, encourages innovation improvement and move and, upgrades asset profitability. The unrestricted market rivalry additionally serves the enthusiasm of buyers by enabling them to practice their privilege of decision over products and enterprises offered in the market.

Ayyagari et al. (2007) examined the connection between the overall size of the SMEs area and the business condition in 76 nations. The significance of MSMEs and the casual economy to pointers of various elements of the business condition was identified. A few parts of the business condition, for example, lower expenses of passage and better credit data sharing, are related to a bigger size of the MSME division, while higher leave costs identified with a more extensive casual economy. 
Terziovski (2010) considered the advancement practice and its exhibition suggestions in SMEs in the assembling division that distinguishes development drivers and their presentation suggestions in the assembling MSMEs. This examination found that SMEs are like huge firms concerning the way that advancement methodology and formal structure are the key drivers of their exhibition. However, they do not seem to use a development culture in a key and organized way. Therefore, MSMEs' performance is likely to improve as they increase the degree to which they mirror large manufacturing firms concerning formal strategy and structure, and to which they recognize that innovation culture and strategy aligned throughout the innovation process.

These literature and studies have contributed to the formulation of variables concerning the financial management of MSMEs in the Philippines, which are deemed necessary.

\section{METHODOLOGY}

This research endeavor applied the descriptive correlational research method, utilizing a researcher-made survey tool to gather the vital information on the profile, financial management practices, and challenges faced by the MSMEs in Danao City, Cebu, Philippines.

The respondents were chosen using a cluster sampling technique was employed so that each type of MSME was adequately represented in the number of participants. There was a total of 354 respondents from the different nature of the business activities of MSMEs. Most respondents were engaged in the trading business. The fewest number of respondents were into the provision of accommodation services.

The researcher-designed survey tool was used in the data gathering process, consisted of three parts. The first part determines the characteristics of the MSMEs in the aspects of the type of business organization, nature of the business, number of years of operation, location, number of employees, estimated capitalization, estimated assets, and average monthly income. The second part pertains to the financial management practices of MSMEs in terms of recording, budgeting, reporting, and inventory management. The third part tackles the challenging experiences confronting the MSMEs based on the aspects of internal control, competitors, promotion, and in dealing with the government agencies.

A pilot testing was conducted among the 15 respondents comprised of five respondents from the manufacturing, trading, and service sectors. The Cronbach's Alpha value of 0.9653 signifies that the self-made questionnaire was highly reliable. The gathered data were statistically treated using frequency, simple percentage, weighted mean, Chisquare test of independence, and ANOVA. 
International Journal of Small Business and Entrepreneurship Research

Vol.8, No.1, pp.53-76, January 2020

Published by ECRTD-UK

Print ISSN: 2053-5821(Print), Online ISSN: 2053-583X (Online)

\section{RESULTS AND DISCUSSIONS}

Table 1 presents the characteristics of MSMEs.

Table 1. Characteristics of the MSMEs $(n=354)$

\begin{tabular}{|c|c|c|}
\hline Indicators & Frequency & Percentage \\
\hline \multicolumn{3}{|l|}{ A. Type of Business Organization } \\
\hline \begin{tabular}{l|l} 
& Sole Proprietorship \\
\end{tabular} & 279 & 78.81 \\
\hline Partnership & 39 & 11.02 \\
\hline Corporation & 24 & 6.78 \\
\hline \begin{tabular}{l|l} 
Cooperative \\
\end{tabular} & 12 & 3.39 \\
\hline \multicolumn{3}{|l|}{ B. Nature of Business } \\
\hline \begin{tabular}{l|l|} 
& Trading/Buy \& Sell \\
\end{tabular} & 153 & 43.22 \\
\hline Food \& Beverage & 103 & 29.10 \\
\hline Service-Oriented & 64 & 18.08 \\
\hline \begin{tabular}{l|l} 
Accommodation \\
\end{tabular} & 34 & 9.60 \\
\hline \multicolumn{3}{|l|}{ C. Number of Years of Operation } \\
\hline $\mid 1-3$ & 139 & 39.27 \\
\hline $4-6$ & 75 & 21.19 \\
\hline $7-10$ & 75 & 21.19 \\
\hline \begin{tabular}{l|l} 
& More than 10 \\
\end{tabular} & 65 & 18.36 \\
\hline \multicolumn{3}{|l|}{ D. Location } \\
\hline \begin{tabular}{l|l} 
& Near the public market \\
\end{tabular} & 105 & 29.66 \\
\hline City proper & 69 & 19.49 \\
\hline Along the highway & 60 & 16.95 \\
\hline Far from the city proper & 56 & 15.82 \\
\hline Along the barangay road & 28 & 7.91 \\
\hline Corner of the road & 27 & 7.63 \\
\hline \begin{tabular}{l|l} 
Near the church \\
\end{tabular} & 9 & 2.54 \\
\hline \multicolumn{3}{|l|}{ E. Number of Employees } \\
\hline \begin{tabular}{l|l} 
& Less than 10 \\
\end{tabular} & 340 & 96.05 \\
\hline $10-99$ & 13 & 3.67 \\
\hline $100-199$ & 1 & 0.28 \\
\hline \multicolumn{3}{|l|}{ F. Estimated Capitalization (in PhP) } \\
\hline \begin{tabular}{l|l} 
& Less than $3,000,000.00$ \\
\end{tabular} & 353 & 99.72 \\
\hline \begin{tabular}{l|l} 
& $3,000,000.00-15,000,000.00$ \\
\end{tabular} & 1 & 0.28 \\
\hline \multicolumn{3}{|l|}{ G. Estimated Assets Owned (in PhP) } \\
\hline \begin{tabular}{l|l} 
& Less than $5,000.00$ \\
\end{tabular} & 4 & 1.13 \\
\hline $5,001.00-10,000.00$ & 33 & 9.32 \\
\hline $10,001.00-20,000.00$ & 58 & 16.38 \\
\hline $20,001.00-30,000.00$ & 35 & 9.89 \\
\hline $30,001.00-50,000.00$ & 69 & 19.49 \\
\hline $50,001.00-100,000.00$ & 44 & 12.43 \\
\hline \begin{tabular}{l|l} 
& More than $100,000.00$ \\
\end{tabular} & 111 & 31.36 \\
\hline \multicolumn{3}{|l|}{ H. Average Monthly Income (in PhP) } \\
\hline \begin{tabular}{l|l} 
Less than $7,890.00$ (Poor) \\
\end{tabular} & 22 & 6.21 \\
\hline $7,890-15,780.00$ (Low Income) & 85 & 24.01 \\
\hline $15,780-31,560.00$ (Lower Middle Income) & 108 & 30.51 \\
\hline $31,560-78,900.00$ (Middle Income) & 74 & 20.90 \\
\hline $78,900-118,350.00$ (Upper Middle Income) & 30 & 8.47 \\
\hline $118,350-157,800.00$ (Upper Income) & 13 & 3.67 \\
\hline More than $157,800.00$ (Rich) & 22 & 6.21 \\
\hline
\end{tabular}


The dominant form of business organization among the various MSMEs business entities in the study environment was a sole proprietorship, which accounts to $78.81 \%$. It is expected that for small businesses, the owners would choose the most straightforward and least complex business organization because of the limited capital, a lesser number of employees, and minimal reportorial requirements from the government.

On the other, 12 cooperatives operate in the city, which accounts to $3.39 \%$. Having this number of cooperative organizations in a single city is an indicator that the people are open to business organizations under a membership basis since, in a cooperative, all the members are the owner. They can participate during the voting at the General Assembly for significant decisions to be carried out.

Moreover, more of the MSMEs in the city were into the trading business, accounting for $43.22 \%$. Among the different nature of the business activity or buying and selling of various commodities, it is one of the most natural means of doing business. Aside from that, the capital requirement is also minimal compared to other business activities. The least number of MSMEs were into the provision of accommodation services like beach resorts, hotels, and pension houses. There were only a few $(9.60 \%)$ of this type of business in the city because Danao City is less urbanized compared to Cebu City. It only acquired to become a city when a multinational company like Mitsumi operated, and other companies like Durano and Sons Cement Company several decades ago.

Also, there were $139(39.27 \%)$ businesses out of 354 that had been in operation for 1 to 3 years, while $65(18.36 \%)$ had operated for more than ten years. These data imply that the MSMEs are still at the start-up stage and had not penetrated the market yet. They still need government support for business sustainability of continuity.

As to location, there were more MSMEs $(29.66 \%)$ that are located near the public market. This location of the business has been considered as the most accessible to the target market since most of the people would go to the open market to buy their needed goods for consumption. So, the chance for business survival is high. Another place that is an accessible business location is near the church. However,t since the area near the church is already congested. There were only a few $(9,2.54 \%)$ who were operating near the Roman Catholic Church in the city proper.

Further, of the 354 MSMEs, the majority (340, 96.05\%) employed less than ten employees, and there was only one business that used from 100-199 workers. Usually, the number of employees depends on the nature, capitalization, and volume of business. Since the SMEs were in the trading business and the amount of activity is relatively minimal, then they only employed a few people or workforce.

Almost all (99.72\%) of the MSMEs had an estimated capital of fewer than three million pesos. This figure can be inferred that the business in the city was predominantly small in size and can qualify for the exemption from the annual income tax and coverage of the Minimum Wage Law if they register their business as a village micro business enterprises at the proper government agency. 
Print ISSN: 2053-5821(Print), Online ISSN: 2053-583X (Online)

Table 2. Financial management practices of MSMEs as to recording

\begin{tabular}{|c|c|c|c|}
\hline & Indicators & Mean & Interpretation \\
\hline 1. & $\begin{array}{l}\text { I keep track and record my daily sales } \\
\text { every day. }\end{array}$ & 3.04 & Moderately Practiced \\
\hline 2. & $\begin{array}{l}\text { I record all my inventory/or stock } \\
\text { purchases in the ledger. }\end{array}$ & 2.89 & Moderately Practiced \\
\hline 3. & $\begin{array}{l}\text { I record all my expenses incurred in the } \\
\text { operation of the business. }\end{array}$ & 3.04 & Moderately Practiced \\
\hline 4. & $\begin{array}{l}\text { I record all taxes, registration charges, fees, } \\
\text { and other payables in the book. }\end{array}$ & 3.04 & Moderately Practiced \\
\hline 5. & $\begin{array}{l}\text { I keep track of all my } \\
\text { collectibles/receivables in the book of } \\
\text { accounts. }\end{array}$ & 2.87 & Moderately Practiced \\
\hline & $\begin{array}{c}\text { Aggregate Mean } \\
\end{array}$ & 2.98 & Moderately Practiced \\
\hline
\end{tabular}

The study got an aggregate mean of 2.98 indicates that the owners of the MSMEs in Danao City practiced recording the cash flows in the course of the business operations in many instances only. There are some owners or even some cases that they failed to record the other ins and outs of the money and physical inventories. As such, they did not adhere to the universal standards of recording all the transactions such as sales, stocks, operating expenses, governmental fees, and receivables.

Keeping financial records organized is a critical element of a successful business (Wagithunu et al., 2014). Everyone in business must keep records. Keeping good records is very important to the company. Good records will help the owner in doing the following: 1) monitoring the progress of the business; 2) preparing the financial statements; identifying sources of the income; 3) keeping track of your deductible expenses; 4) keeping track of the basis in property; 5) preparing the tax returns; 6) supporting items reported in the tax returns.

Table 3. Financial management practices of MSMEs as to budgeting

\begin{tabular}{|c|c|c|c|}
\hline & Indicators & Mean & Interpretation \\
\hline 1. & $\begin{array}{l}\text { I make forecasts on the future demand and } \\
\text { supply of the goods that I produced or sell. }\end{array}$ & 2.95 & Moderately Practiced \\
\hline 2. & $\begin{array}{l}\text { I make projections on the future operating } \\
\text { expenses of my businesses. }\end{array}$ & 2.85 & Moderately Practiced \\
\hline 3. & $\begin{array}{l}\text { I make a budgetary allocation on all the } \\
\text { expenses that I incurred in running the } \\
\text { business. }\end{array}$ & 3.06 & Moderately Practiced \\
\hline 4. & $\begin{array}{l}\text { I make a budget schedule of all the goods } \\
\text { that I produced or sell. }\end{array}$ & 3.08 & Moderately Practiced \\
\hline 5. & $\begin{array}{l}\text { I do not spend more than my } \\
\text { income/revenue. }\end{array}$ & 2.99 & Moderately Practiced \\
\hline & Aggregate Mean & 2.99 & Moderately Practiced \\
\hline
\end{tabular}

The highest weighted mean of 3.08 was observed in making a budget schedule of all the goods that the business produces or the goods that were being sold. However, this 
practice was only found in many cases (moderately practiced). So, there are MSME owners or management who did not make plans on the logical quantity of goods to be produced for those businesses that are engaged in production or manufacturing or the products to be sold for certain times of the year. The consequence of this practice is the probability of overstocking or shortage of inventories during peak periods. Overstocking will lead to losses, while understocking will lead to opportunity loss. Both outcomes have an internal impact on the profitability of the business.

On the other side, the lowest mean of 2.85 was in making projections on the future operating expenses of the businesses that are being studied. This indicates that they only moderately practiced the means of economizing the financial resources to be used for operating costs. The drawback of this training is that a few utilities are not being saved because they only make use of any funds as much as they want as long as they have the money to pay for the bills per month.

The aggregate mean of 2.99 indicates that the MSMEs did not observe the proper means of budgeting the monetary and non-monetary resources and assets of the business, like the projection of future inventories and other expenses in the industry.

Mohamed and Ali (2013) contended that vital planning, participatory planning, budgetary control had a positive connection to fast execution and recommended participatory planning had a progressively critical impact on the company's presentation too. Kimunguyi et al. (2015) further contended that high spending the board rehearses emphatically affected budgetary execution and suggested advancement and usage of practical approaches and guidelines for spending the executives.

Table 4. Financial management practices of MSMEs as to reporting

\begin{tabular}{|c|l|c|l|}
\hline 1. & \multicolumn{1}{|c|}{ Indicators } & Mean & \multicolumn{1}{|c|}{ Interpretation } \\
\hline 2. & & 3.16 & Moderately Practiced \\
government. & $\begin{array}{l}\text { I claim input tax from all my inventory } \\
\text { purchases. }\end{array}$ & 3.01 & Moderately Practiced \\
\hline 3. & $\begin{array}{l}\text { I do or prepare all the recording and } \\
\text { reportorial requirements from the } \\
\text { government. }\end{array}$ & 3.07 & Moderately Practiced \\
\hline 4. & $\begin{array}{l}\text { I hire an external bookkeeper/ accountant } \\
\text { to prepare the reports and returns to be } \\
\text { submitted to the government agencies. }\end{array}$ & 2.38 & Less Practiced \\
\hline 5. & $\begin{array}{l}\text { I comply and submit on time all the } \\
\text { reportorial requirements required by the } \\
\text { government agencies like income tax } \\
\text { returns and financial statements like } \\
\text { income statement, cash flow, and balance } \\
\text { sheet, etc. }\end{array}$ & 3.12 & Moderately Practiced \\
\hline & \multicolumn{1}{|c|}{ Aggregate Mean } & $\mathbf{2 . 9 5}$ & Moderately Practiced \\
\hline
\end{tabular}


According to the respondents, they report all their revenues or sales to the government, both at the BIR and the local government unit (LGU) of the City of Danao, in some instances (moderately practiced). This item obtained the highest weighted mean of 3.16. So, some business owners practiced any means of reducing their tax liabilities to the national and local governments, which is known as tax avoidance. Some used fraud to lessen or defeat their tax liabilities, which is considered a criminal offense, and whoever may be caught will be charged by tax evasion. Whether the means are legal or illegal, these practices are happening in the economy, not only in Danao City but in other parts of the Philippines.

Conversely, the hiring of an external bookkeeper or accountant to prepare the reports and income tax returns to be submitted to government agencies like the Bureau of Internal Revenue (BIR) was less practiced, based on the weighted mean of 2.38. Again, only those large SMEs has the financial capacity to pay the monthly retainers for bookkeeper and accountant to keep their accounting records accurate and prepare the BIR documents. The small businesses usually would be required to pay the tax stamp.

Further, the aggregate weighted mean of 2.95 indicates that the MSMEs complied with the reportorial requirements of the government in some cases only. In terms of submitting their financial statements and records of the exact gross annual sales on the yearly income taxes to be paid to the BIR at the end of the calendar year also have less compliance. Even though the last filing of the Income Tax Returns (ITR) is usually on the $15^{\text {th }}$ day of April in the succeeding year, the Philippine government follows the fiscal year for the budgeting.

Following the budgetary wellbeing of a business and its development after some time is essential: to arrange first business exchanges, monitor solicitations, yet additionally for legitimate purposes.

Table 5. Financial management practices of MSMEs as to inventory management

\begin{tabular}{|c|l|c|l|}
\hline \multicolumn{1}{|c|}{ Indicators } & Mean & \multicolumn{1}{|c|}{ Interpretation } \\
\hline 1. & $\begin{array}{l}\text { I record all new stock purchases in the } \\
\text { book. }\end{array}$ & 2.86 & Moderately Practiced \\
\hline 2. & $\begin{array}{l}\text { I use/apply technology in recording the ins } \\
\text { and outs of my stocks like Point of Sales } \\
\text { System (POS), etc. }\end{array}$ & 2.28 & Less Practiced \\
\hline 3. & $\begin{array}{l}\text { I conduct inventory or physical counting of } \\
\text { stocks regularly. }\end{array}$ & 2.94 & Moderately Practiced \\
\hline 4. & $\begin{array}{l}\text { I practice the first-in and last-out inventory } \\
\text { management system. }\end{array}$ & 2.81 & Moderately Practiced \\
\hline 5. & $\begin{array}{l}\text { I project the required level of inventory of } \\
\text { stocks needed on a regularly specified time. }\end{array}$ & 2.66 & Moderately Practiced \\
\hline & \multicolumn{1}{|c|}{ Aggregate Mean } & $\mathbf{2 . 7 1}$ & Moderately Practiced \\
\hline
\end{tabular}

Based on the answers of the respondents, they moderately practiced the conduct of inventory or physical counting of stocks regularly, either once a month or week, as 
shown by the weighted mean of 2.94. So, there are some instances that the MSME owners would only rely on the honesty of their workers or the presumption that there was no pilferage of any goods by anyone.

Nevertheless, the usage or application of technology in recording the ins and outs of stocks or inventories like Point of Sales System (POS), etc. was less practiced based on the weighted mean of 2.28. Since the software and the hardware requirements for any automated inventory systems like POS are relatively expensive, there were only a few business entities who can afford to buy computer units and the software for the automation of the recording of all the business transactions. It can be noted that there were more MSMEs whose income was at the lower-middle-income bracket. So, these businesses would only use manual counting and recording of their sales, expenses, and other business dealings.

The aggregate mean of 2.71, reveals that the MSMEs moderately practiced the inventory management systems. This is because physical counting and regular tracking of the stocks is a tedious and time-consuming activity on the part of the business owners. So, they do not have the time and energy to perform this practice since most SMEs operate for more than eight hours.

Stock empowers an organization to help the client administration, calculated, or fabricating exercises in circumstances where buy or production of the things cannot fulfill the interest. This could emerge either on account of the speed of buying, or because assembling is excessively extended, or because the amounts requested could not be given without stocks, i.e., the interest rate surpasses the most extreme supply rate (Wild, 2017).

Williams et al. (2005) further clarified that the valuation of stock and the expenses of products sold is of fundamental significance to directors and outer clients of budget reports. Much of the time, the stock is an organization's most colossal resource, and the expense of products sold is its most effective cost. These two records substantially affect the budget summary subtotals and proportions utilized in assessing the dissolvability and gainfulness of the business. A few distinct techniques for estimating stock and of determining the expense of products sold are adequate under sound accounting guidelines. These various strategies may create altogether multiple outcomes, both in an organization's financial reports and its assessment forms. 
Print ISSN: 2053-5821(Print), Online ISSN: 2053-583X (Online)

Table 6. Challenges of MSMEs as to internal management

\begin{tabular}{|c|c|c|c|}
\hline & Indicators & Mean & Interpretation \\
\hline 1. & $\begin{array}{l}\text { The management of employees/people is a } \\
\text { hassle to the manager of the business. }\end{array}$ & 2.21 & Less Challenging \\
\hline 2. & $\begin{array}{l}\text { Internal theft or pilferage causes some } \\
\text { threats towards financial losses to the } \\
\text { business. }\end{array}$ & 2.64 & Fairly Challenging \\
\hline 3. & $\begin{array}{l}\text { The required regular maintenance of the } \\
\text { machines, tools, and equipment of the } \\
\text { business establishment is costly to the } \\
\text { management or owner. }\end{array}$ & 2.73 & Fairly Challenging \\
\hline 4. & $\begin{array}{l}\text { The changes in the market trend cause } \\
\text { some future risks to the survival of the } \\
\text { business. }\end{array}$ & 2.85 & Fairly Challenging \\
\hline 5. & $\begin{array}{l}\text { Natural calamities cause some damages to } \\
\text { the assets of the business and increase } \\
\text { maintenance and repair costs. }\end{array}$ & 2.82 & Fairly Challenging \\
\hline & $\begin{array}{c}\text { Aggregate Mean } \\
\end{array}$ & 2.65 & Fairly Challenging \\
\hline
\end{tabular}

The highest mean of 2.85 was observed on the aspect of the challenges experienced by the MSMEs towards the changes in the market trend that caused some future risks on the survival of the business. So, in many instances, the volatility of the preferences of the customers on various commodities in the market poses some challenge to the MSMEs since now and then, there will be changes in the preferred style of goods, design, functionality, and scheme of purchase that will be introduced in the market. So if this happens, the business will face the problem of unsold inventories that would be out of demand already. Aside from that, other issues such as inflation and changing governmental policies will also affect the existence of business enterprises. So, the owners and management should devise plans on how to counter the adverse effect of these external factors affecting the operation of the business.

On the other hand, the lowest mean of 2.21 was found in the management of employees/people that cause hassle to the manager of the business. Since time immemorial, dealing with the differences in the human dynamics of the company is quite challenging for the MSMEs. It has to comply with the provisions of the minimum wage law and other statutory benefits, along with the difference in the attitudes of the people. All of these factors would have an impact on the efficiency and productivity of the people in the business organization

The aggregate mean of 2.65, indicates that the MSMEs find the problems in terms of the internal management business as challenging in many cases. So, there are more aspects in the management of the people, machines, tools, equipment, and detecting internal theft that require much attention on the part of the owners.

As a small business owner, one should know that implementing properly designed controls with limited resources might be challenging. However, not addressing deficiencies can expose the business to operational and financial risks and losses. 
Luckily, there are steps that the proprietor can take to help avert and distinguish extortion in the organization. The most popular sorts of inside control shortcomings recognized in private companies can frequently be relieved through executing a blend of against extortion controls and marginally altering existing procedures. The accompanying five inside control difficulties are probably the most generally found in independent companies: partition of obligations, arrangements, and methodology, documentation, oversight and survey, and client access rights for data frameworks.

Table 7. Challenges of MSMEs in dealing with the competitors

\begin{tabular}{|c|c|c|c|}
\hline & Indicators & Mean & Interpretation \\
\hline 1. & $\begin{array}{l}\text { The absence of barriers to entry makes the } \\
\text { competition in the market very stiff. }\end{array}$ & 2.82 & Fairly Challenging \\
\hline 2. & $\begin{array}{l}\text { The practice of other businesses in selling } \\
\text { or producing substandard products or of } \\
\text { low quality but cheap that causes some } \\
\text { threats to the survival of the company. }\end{array}$ & 2.85 & Fairly Challenging \\
\hline 3. & $\begin{array}{l}\text { Cut-throat competition practices of the } \\
\text { competitors cause some problems for the } \\
\text { business. }\end{array}$ & 2.78 & Fairly Challenging \\
\hline 4. & $\begin{array}{l}\text { The absence of strict implementation of } \\
\text { laws to avoid too much competition is a } \\
\text { headache to business management. }\end{array}$ & 2.77 & Fairly Challenging \\
\hline \multirow[t]{2}{*}{5.} & $\begin{array}{l}\text { The entry of competitors during high } \\
\text { season causes market distortion. }\end{array}$ & 2.78 & Fairly Challenging \\
\hline & $\begin{array}{c}\text { Aggregate Mean } \\
\end{array}$ & 2.80 & Fairly Challenging \\
\hline
\end{tabular}

The highest mean of 2.85 was found on the practice of other businesses in selling or producing products that are substandard or of low quality but cheap and cause some threats to the survival of the company. In some cases, the owners or management of the MSMEs find the presence of China-made products that are cheaper than the standard product as a potential threat that might get a sizable share of the market. They considered these business entities as challenging to a moderate extent.

On the other side, the absence of strict implementation of laws to avoid too much competition is a headache to the business management considered as challenging in many instances, based on the weighted mean of 2.77. This result denotes that there was a problem in the context of the strict implementation of Anti-Competition Law and Anti-Trust Law in the Philippines. The provisions of these two legislative enactments about the protection of local industries are complete in substance, but the loophole was on the implementation. That is the reason why there are lots of market distortions where the local players suffer to some extent.

The aggregate mean of 2.80 indicates that the problems of the MSMEs that relate to dealing with the competitors were considered as challenging in many instances. With the numerous business entities that operate in Danao City that fall under the MSME category, the competition for survival is very stiff. 
Under the Philippines' Republic Act No. 10667, the State recognizes that past measures are undertaken to liberalize critical sectors in the economy that need to be reinforced by measures that safeguard competitive conditions. The State also recognizes that the provision of equal opportunities to all promotes the entrepreneurial spirit, encourages private investments, facilitates technology development and transfer, and enhances resource productivity.

This section shows the data on the challenges experienced by the owners of MSMEs in the context of promoting the products and services being offered by the business.

\section{Table 8. Challenges that Confronts the MSMEs as to sales promotions}

\begin{tabular}{|c|c|c|c|}
\hline & Indicators & Mean & Interpretation \\
\hline 1. & $\begin{array}{l}\text { Engaging in online selling increases } \\
\text { marketing costs, but there is uncertainty } \\
\text { about whether there is an increase in sales } \\
\text { or not. }\end{array}$ & 2.39 & Less Challenging \\
\hline 2. & $\begin{array}{l}\text { If the business will depend on walk-in } \\
\text { customers/buyers, it does guarantee } \\
\text { stable/regular revenue/sales throughout the } \\
\text { year. }\end{array}$ & 2.82 & Fairly Challenging \\
\hline 3. & $\begin{array}{l}\text { The provision of discounts and customer } \\
\text { rewards causes high promotion costs. }\end{array}$ & 2.68 & Fairly Challenging \\
\hline 4. & $\begin{array}{l}\text { It is difficult to sell or promote products } \\
\text { that are not yet known in the market. }\end{array}$ & 2.84 & Fairly Challenging \\
\hline \multirow[t]{2}{*}{5.} & $\begin{array}{l}\text { The seasonality of some products causes } \\
\text { some losses at some periods of the year. }\end{array}$ & 2.78 & Fairly Challenging \\
\hline & Aggregate Mean & 2.70 & Fairly Challenging \\
\hline
\end{tabular}

The problems with the difficulty of selling or promoting products/goods that are not yet known in the market were considered as challenging in many cases, based on the weighted mean of 2.84. This aspect obtained the highest mean. So, those MSMEs that sell new products in the market experienced significant challenges on how to forge awareness to the target market to be able to gain sales since the typical consumer buying behavior is that they buy products that are already known in the market.

The lowest mean of 2.39 was observed in the aspect of engaging in online selling, which increases marketing costs, but there is uncertainty whether there is an increase in sales or not. This means that hiring in selling using a social platform does not guarantee an increase in sales or revenue. This means that even the emergence of various virtual forms of advertising and promotion still posing a few challenges on the MSMEs. However, one cannot discount the fact that online selling nowadays has helped small businesses to increase.

Moreover, the aggregate mean of 2.70 indicates that the challenges that are experienced by the MSMEs relating to sales promotion were in many cases. So there are many instances that the owners were confronted with problems on how to sustain their business in the market through advertising and promotions. 
In the present aggressive market, beginning an independent venture is sufficiently challenging. Entrepreneurs need to shuffle factual data, current needs, future arranging, and the entirety of the startling interferences every day brings. Discovering time to showcase the business, or merely to figure out how to sell it, is not easy. The following are the most common marketing challenges business owners face today, such as funding, standing out, finding customers, getting found by customers, retaining valuable customers, expansion, one's to-do list, and burnout.

This section shows the data on the challenges experienced by the owners of MSMEs in dealing with the government agencies that regulate the operations of the business.

Table 9. Challenges of MSMEs in dealing with government agencies

\begin{tabular}{|c|l|c|l|}
\hline & \multicolumn{1}{|c|}{ Indicators } & Mean & \multicolumn{1}{|c|}{ Interpretation } \\
\hline 1. & $\begin{array}{l}\text { The micro, small and medium-sized enterprises } \\
\text { experience problems in securing a business permit } \\
\text { from the local government Unit }\end{array}$ & 2.77 & Fairly Challenging \\
\hline 2. & $\begin{array}{l}\text { The management experiences complexity in } \\
\text { complying with the general building requirements } \\
\text { because it causes high costs in building the required } \\
\text { facilities and amenities like elevators for tall rise } \\
\text { buildings, PWD ramp, fire exit, etc. }\end{array}$ & 2.54 & Fairly Challenging \\
\hline 3. & $\begin{array}{l}\text { The establishment experienced some problems in } \\
\text { complying with the proper management of wastes } \\
\text { (solid and wastewater) produced by the business. }\end{array}$ & 2.44 & Less Challenging \\
\hline 4. & $\begin{array}{l}\text { The establishment experienced some problems with } \\
\text { the imposition of many tax payables from different } \\
\text { government agencies. }\end{array}$ & 2.52 & Fairly Challenging \\
\hline 5. & $\begin{array}{l}\text { Complying the Environmental Compliance } \\
\text { Certificate (ECC) is tedious and complicated. }\end{array}$ & 2.56 & Fairly Challenging \\
\hline & \multicolumn{2}{|c|}{ Aggregate Mean } & Fairly Challenging \\
\hline
\end{tabular}

The highest mean of 2.77 was somewhat challenging as the MSMEs experienced problems in securing business or mayor's permits from the LGU of Danao City, where their businesses are operating. This result shows that in many cases (challenging), the MSMEs in Danao City experienced the problems that relate to the compliance of the different regulatory requirements needed to obtain the business or mayor's permit. These are the sanitary permit, building permit, fire safety clearance, etc.

On the other hand, the lowest mean of 2.44 was on some problems in complying with the proper management of wastes produced. Based on experience, the most common problem was on segregation of the garbage from biodegradable, recyclable, and hazardous. Another issue was on the cost incurred in setting up the wastewater treatment facility to avoid dumping of unsafe wastes water directly to the canals and any bodies of water.

The aggregate mean of 2.57 reflects that the MSMEs in Danao City is confronted with challenges in dealing with the government agencies. This result indicates that in many instances, the owners and management of the MSMEs face difficulties in making a transaction with the government agencies that are tasked to regulate the operation of business entities. The extent of these problems depends on the education and nature of the business operation. 
This result relates to the result of the study conducted by the World Bank Group in 2018 that stipulates that the rank of the Philippines declined from 99th to 113th among 190 countries in terms of ease of doing business. In the ASEAN Region, the Philippines lags behind Singapore, Malaysia, Thailand, Indonesia, Brunei, Vietnam, and the regional average for East Asia and the Pacific while the Philippines advances from Cambodia, Lao PDR, and Myanmar (Mendoza et al., 2015).

Table 10. Relationship between characteristics of MSMEs and their financial management practices

\begin{tabular}{|c|c|c|c|c|c|}
\hline & $\mathbf{X}^{2}$ & df & cv & Significance & Result \\
\hline \multicolumn{6}{|l|}{ A. Recording } \\
\hline Type of Business Org & 16.695 & 9 & 16.919 & Not Significant & Ho Accepted \\
\hline Nature of Business & 9.201 & 9 & 16.919 & Not Significant & Ho Accepted \\
\hline Years of Operation & 10.864 & 9 & 16.919 & Not Significant & Ho Accepted \\
\hline Location & 20.241 & 18 & 28.869 & Not Significant & Ho Accepted \\
\hline Number of Employees & 8.234 & 6 & 12.592 & Not Significant & Ho Accepted \\
\hline Capitalization & 1.202 & 3 & 7.815 & Not Significant & Ho Accepted \\
\hline Assets & 17.670 & 18 & 28.869 & Not Significant & Ho Accepted \\
\hline Income & 31.036 & 18 & 28.869 & Significant & Ho Rejected \\
\hline \multicolumn{6}{|l|}{ B. Budgeting } \\
\hline Type of Business Org & 16.622 & 9 & 16.919 & Not Significant & Ho Accepted \\
\hline Nature of Business & 21.681 & 9 & 16.919 & Significant & Ho Rejected \\
\hline Years of Operation & 5.836 & 9 & 16.919 & Not Significant & Ho Accepted \\
\hline Location & 28.594 & 18 & 28.869 & Not Significant & Ho Accepted \\
\hline Number of Employees & 5.634 & 6 & 12.592 & Not Significant & Ho Accepted \\
\hline Capitalization & 1.646 & 3 & 7.815 & Not Significant & Ho Accepted \\
\hline Assets & 15.523 & 18 & 28.869 & Not Significant & Ho Accepted \\
\hline Income & 28.224 & 18 & 28.869 & Not Significant & Ho Accepted \\
\hline \multicolumn{6}{|l|}{ C. Reporting } \\
\hline Type of Business Org & 12.733 & 9 & 16.919 & Not Significant & Ho Accepted \\
\hline Nature of Business & 13.581 & 9 & 16.919 & Not Significant & Ho Accepted \\
\hline Years of Operation & 5.418 & 9 & 16.919 & Not Significant & Ho Accepted \\
\hline Location & 23.166 & 18 & 28.869 & Not Significant & Ho Accepted \\
\hline Number of Employees & 7.591 & 6 & 12.592 & Not Significant & Ho Accepted \\
\hline Capitalization & 1.533 & 3 & 7.815 & Not Significant & Ho Accepted \\
\hline Assets & 35.075 & 18 & 28.869 & Significant & Ho Rejected \\
\hline Income & 24.701 & 18 & 28.869 & Not Significant & Ho Accepted \\
\hline \multicolumn{6}{|l|}{ D. Inventory } \\
\hline Type of Business Org & 17.993 & 9 & 16.919 & Significant & Ho Rejected \\
\hline Nature of Business & 16.937 & 9 & 16.919 & Significant & Ho Rejected \\
\hline Years of Operation & 5.125 & 9 & 16.919 & Not Significant & Ho Accepted \\
\hline Location & 25.763 & 18 & 28.869 & Not Significant & Ho Accepted \\
\hline Number of Employees & 8.366 & 6 & 12.592 & Not Significant & Ho Accepted \\
\hline Capitalization & 2.167 & 3 & 7.815 & Not Significant & Ho Accepted \\
\hline Assets & 25.531 & 18 & 28.869 & Not Significant & Ho Accepted \\
\hline Income & 36.165 & 18 & 28.869 & Significant & Ho Rejected \\
\hline
\end{tabular}

There is a significant relationship between the financial management practices of the MSMEs in terms of recording and their average monthly income. This result connotes that the means of recording the transactions in the ordinary course of business operation has something to do with the number of revenues generated by the business entity. 
Moreover, another significant relationship was observed in the financial management practice in the aspect of budgeting and the nature of business. So, whether the company is into trading, food and beverage, provision of services, and accommodation, it is related to their budgeting system or apportionment of the scarce business monetary and non-monetary resources. Further, there is also a significant relationship between the financial management practices of reporting and the number of estimated assets owned by the MSMEs in Danao City, Cebu.

These data correlate with the size of the business where the medium scale business entity has more reportorial requirements from the various government agencies compared to the micro and small-scale business enterprises.

A significant relationship also exists in the inventory management practice of the business and the type of business. This result denotes whether the business enterprise is a sole proprietorship, partnership, and corporation, or cooperative; it is associated with how the owners and the mangers operate its inventories. The more complex and varied the nature of stocks are, the more complex the needed inventory system to be applied by the business.

Inventory management of the MSMEs and the nature of business is likewise significant. This result has something to do with whether the company is into buying and selling various commodities or the provision of services because the inventory management of the stocks would be different. In trading, the flow of physical shares is more voluminous compared to the service-oriented business entity.

Lastly, inventory management is significantly related, as well as to the amount of average monthly income of the MSMEs. This means that the bigger the income earned by the business, it has a significant variation in the manner of managing the physical stocks of the company.

Table 11. Relationship between characteristics of MSMEs and their challenges

\begin{tabular}{|l|r|r|r|l|l|}
\hline & \multicolumn{1}{|c|}{$\mathbf{X}^{\mathbf{2}}$} & $\mathbf{d f}$ & $\mathbf{c v}$ & \multicolumn{1}{|c|}{ Significance } & \multicolumn{1}{|c|}{ Result } \\
\hline A. Internal Mgt & & & & & \\
\hline Type of Business Org & 14.938 & 9 & 16.919 & Not Significant & Ho Accepted \\
\hline Nature of Business & 6.433 & 9 & 16.919 & Not Significant & Ho Accepted \\
\hline Years of Operation & 6.522 & 9 & 16.919 & Not Significant & Ho Accepted \\
\hline Location & 30.698 & 18 & 28.869 & Significant & Ho Rejected \\
\hline Number of Employees & 6.645 & 6 & 12.592 & Not Significant & Ho Accepted \\
\hline Capitalization & 3.031 & 3 & 7.815 & Not Significant & Ho Accepted \\
\hline Assets & 21.347 & 18 & 28.869 & Not Significant & Ho Accepted \\
\hline Income & 19.184 & 18 & 28.869 & Not Significant & Ho Accepted \\
\hline B. Competitors & & & & & \\
\hline Type of Business Org & 20.003 & 9 & 16.919 & Significant & Ho Rejected \\
\hline Nature of Business & 22.407 & 9 & 16.919 & Significant & Ho Rejected \\
\hline Years of Operation & 3.840 & 9 & 16.919 & Not Significant & Ho Accepted \\
\hline Location & 34.553 & 18 & 28.869 & Significant & Ho Rejected \\
\hline Number of Employees & 8.665 & 6 & 12.592 & Not Significant & Ho Accepted \\
\hline
\end{tabular}


International Journal of Small Business and Entrepreneurship Research

Vol.8, No.1, pp.53-76, January 2020

Published by ECRTD-UK

Print ISSN: 2053-5821(Print), Online ISSN: 2053-583X (Online)

\begin{tabular}{|l|r|c|r|l|l|}
\hline Capitalization & 2.167 & 3 & 7.815 & Not Significant & Ho Accepted \\
\hline Assets & 12.842 & 18 & 28.869 & Not Significant & Ho Accepted \\
\hline Income & 27.024 & 18 & 28.869 & Not Significant & Ho Accepted \\
\hline C. Promotion & & & & & \\
\hline Type of Business Org & 15.756 & 9 & 16.919 & Not Significant & Ho Accepted \\
\hline Nature of Business & 19.728 & 9 & 16.919 & Significant & Ho Rejected \\
\hline Years of Operation & 12.250 & 9 & 16.919 & Not Significant & Ho Accepted \\
\hline Location & 32.838 & 18 & 28.869 & Significant & Ho Rejected \\
\hline Number of Employees & 4.495 & 6 & 12.592 & Not Significant & Ho Accepted \\
\hline Capitalization & 2.346 & 3 & 7.815 & Not Significant & Ho Accepted \\
\hline Assets & 10.286 & 18 & 28.869 & Not Significant & Ho Accepted \\
\hline Income & 32.898 & 18 & 28.869 & Significant & Ho Rejected \\
\hline D. Dealing with Govt & & & & & \\
\hline Agencies & & & & & \\
\hline Type of Business Org & 12.458 & 9 & 16.919 & Not Significant & Ho Accepted \\
\hline Nature of Business & 7.674 & 9 & 16.919 & Not Significant & Ho Accepted \\
\hline Years of Operation & 7.537 & 9 & 16.919 & Not Significant & Ho Accepted \\
\hline Location & 18.224 & 18 & 28.869 & Not Significant & Ho Accepted \\
\hline Number of Employees & 13.597 & 6 & 12.592 & Significant & Ho Rejected \\
\hline Capitalization & 3.380 & 3 & 7.815 & Not Significant & Ho Accepted \\
\hline Assets & 15.712 & 18 & 28.869 & Not Significant & Ho Accepted \\
\hline Income & 25.167 & 18 & 28.869 & Not Significant & Ho Accepted \\
\hline
\end{tabular}

There is a significant relationship between the challenges of the MSMEs about internal management and the location of the business. This result denotes whether the company is easily accessible to the buyer or target market, is related to the problems of managing the people, probing internal theft, and many more.

Additionally, the issue of competition is also significantly correlated with the type of business organization. This result means that the legal form of business is related to how to manage the competitiveness of the market for future survival and sustainability.

The challenge of the management of competition is also significantly related to the nature of business. Meaning, whether the company is into service provision and buying and selling of different commodities, it is connected with the strategic approach to winning against the competitors.

Another significant relationship is also observed in the sales promotion and the nature of the MSME business. These data connect to the fact the advertising the products and services offered by the MSMEs are dependent on the type of commodities being offered to the consumers.

The issue of the promotional strategy employed by the MSMEs is also significantly related to the average monthly income of the business. Since any promotional activity entails cost outlay, so the type of promotions is also associated with the income of the company because it affects the affordability on the medium of advertising to be utilized. 
Finally, the challenges experienced by the MSMEs in the aspect of dealing with the various government agencies are also significantly related to the number of employees. This is substantially associated with the governmental legislation about the compliance of the Labor Code relating to the number of people being employed by the business. There is a significant difference in the responses relating to the financial management practices of the MSME owners in Danao City, Cebu in terms of budgeting.

Table 12. Difference in the financial management practices of MSMEs

\begin{tabular}{|c|r|r|r|l|l|}
\hline Grouped By & \multicolumn{1}{|c|}{ df } & $\begin{array}{c}\text { F- } \\
\text { value }\end{array}$ & $\begin{array}{c}\text { P- } \\
\text { Value }\end{array}$ & Significance & Results \\
\hline A. Recording & & & & & \\
\hline Between Group & 4 & 2.36 & 0.051 & $\begin{array}{l}\text { Not } \\
\text { Significant }\end{array}$ & Ho Accepted \\
\hline Within Group & 1765 & & & & \\
\hline Total & 1769 & & & & \\
\hline B. Budgeting & & & & & Ho Rejected \\
\hline Between Group & 4 & 3.55 & 0.007 & Significant & \\
\hline Within Group & 1765 & & & & \\
\hline Total & 1769 & & & & Ho Rejected \\
\hline C. Reporting & & & & & \\
\hline Between Group & 4 & 33.69 & 0.000 & Significant & \\
\hline Within Group & 1765 & & & & Ho Rejected \\
\hline Total & 1769 & & & & \\
\hline D. Inventory & & & & & \\
\hline Between Group & 4 & 20.32 & 0.000 & Significant & \\
\hline Within Group & 1765 & & & & \\
\hline Total & 1769 & & & & \\
\hline
\end{tabular}

This proves that their method of allocating the limited financial resources of the business, including the projection of future demand-supply of the goods that the company produces. Additionally, there is also another significant difference in the financial management practices of the MSME owners in the study site in the aspect of reporting the business transactions to the proper government agencies. Since different government agencies regulate the operation of a sole proprietorship business from a corporation and a cooperative, then the reportorial requirements also varied, especially about tax payment. Aside from that, the manner of paying the taxes also differs.

A significant difference is also observed in the financial management practices in terms of inventory management of the different MSMEs in the study area. This result denotes that the control of the inflow and outflow of physical inventories depend on the orientation of the owner and the nature of business as well. 
Print ISSN: 2053-5821(Print), Online ISSN: 2053-583X (Online)

Table 13. Difference in the challenges of MSMEs

\begin{tabular}{|l|r|r|r|l|l|}
\hline \multicolumn{1}{|c|}{ Grouped By } & df & $\begin{array}{c}\text { F- } \\
\text { value }\end{array}$ & $\begin{array}{c}\text { P- } \\
\text { Value }\end{array}$ & Significance & Results \\
\hline A. Internal Mgt. & & & & & \\
\hline Between Group & 4 & 20.42 & 0.000 & Significant & Ho Rejected \\
\hline Within Group & 1765 & & & & \\
\hline Total & 1769 & & & & \\
\hline B. Competitors & & & & & \\
\hline Between Group & 4 & 0.44 & 0.782 & Not Significant & Ho Accepted \\
\hline Within Group & 1765 & & & & \\
\hline Total & 1769 & & & & \\
\hline C. Promotion & & & & & Ho Rejected \\
\hline Between Group & 4 & 10.36 & 0.000 & Significant & \\
\hline Within Group & 1765 & & & & \\
\hline Total & 1769 & & & & \\
\hline $\begin{array}{l}\text { D. Dealing with Govt. } \\
\text { Agencies }\end{array}$ & & & & & \\
\hline Between Group & 4 & 4.89 & 0.001 & Significant & Ho Rejected \\
\hline Within Group & 1765 & & & & \\
\hline Total & 1769 & & & & \\
\hline
\end{tabular}

There is a significant difference in the responses of the owners of the MSMEs relating to the challenges that they have experienced in the daily management of the business. This result is attributed to the fact that the problems in the market depend on the nature of the company, several workers, among others, also with the economic and other external factors.

Also, a significant difference is found on the various points of view of the business owners on the challenges that they have experienced in promoting the products and services that they offer to the market.

This means that the relative marketability of the products is dependent on the importance of such products to the target market, the location, the economic circumstance of the people, and many more. So those businesses that are huge in volume have more concerns in hitting more sales compared to smaller-scale business entities.

Moreover, there is also a significant difference in the answers about the challenges in dealing with the government agencies in which business permit will be obtained, and taxes will be paid. This difference is also related to the nature of the product being produced or sold by the business enterprise since there are goods that are required to obtain an additional license from different government agencies. For example, if the business involves marketing and distributing medicines, then a permit from the Bureau of Food and Drugs should be obtained other than the business permit from the local government unit where the business is operating. 
However, there is no significant difference in the perceptions of the numerous respondents on their challenging experience relating to competition in marketing or in dealing with the existing competitors. Thus, the null hypothesis is accepted.

\section{CONCLUSION}

The owners and management of the MSMEs in Danao City do not practice the generally accepted standards on the financial management and control of the business, which poses some threats to its sustainability, considering that their predominant size, the volume of assets and revenue earned is relatively low or minimal. Even though the MSMEs are considered small in size, there must be adherence to the proper accounting, auditing, and internal control to ensure that the limited or scarce resources are allocated and that adequate forecasting for revenue and expenses are undertaken to avoid overstocking and opportunity loss in case of shortage during peak season. Given the significant role played by the MSMEs in boosting the local economies of the Philippines, especially the City of Danao, Cebu in the context of alleviating the unemployment rate and providing income to lots of people, the Department of Trade and Industry (DTI) in collaboration with the LGU should implement programs and policies that are geared towards helping the thriving small and medium-sized business enterprises to survive in the long-run.

\section{RECOMMENDATIONS}

The researchers recommend that the LGU may use the proposed position paper as the basis in enacting an ordinance that would stipulate the vital role of the MSMEs and proposing measures on how to widen the financial literacy of the owners or management. The city will give preferential treatment to the MSMEs when they obtain business or mayor's permit so that they will not find more problems in complying with the governmental regulations. Further, a seminar-workshops conducted by the city local government unit in cooperation with the Department of Trade and Industry Business Centre about financial literacy among the owners and managers of MSMEs.

\section{REFERENCES}

Aldaba, R. (2010). SMEs access to finance: Philippines. Small and Medium Enterprises (SMEs) access to finance in selected East Asian economies. ERIA Research Project Report, 14, 291-350. Retrieved from http://bit.ly/305K6br

Ayyagari, M. Beck, T., and Demirguc-Kunt, A. (2007). Small and medium enterprises across the globe: A new database. The World Bank. Retrieved from http://bit.ly/2ZWSFVB

Baack, D. W., Harris, E. G., and Baack, D. (2013). International marketing (Vol. 3). Sage. Retrieved from http://bit.ly/36iEPQ1

Belke, A., and Gros, D. (2002). Designing EU-US Atlantic monetary relations: Exchange rate variability and labour markets. World Economy, 25(6), 789-813. Retrieved from http://bit.ly/2RljoJW

Brigham, E. F., \& Ehrhardt, M. C. (2013). Financial management: Theory \& practice. Cengage Learning. Retrieved from http://bit.ly/36r7geI

Buchanan, J. M. (2014). Public finance in democratic process: Fiscal institutions and individual choice. UNC Press Books. Retrieved from http://bit.ly/37mlIWu 
International Journal of Small Business and Entrepreneurship Research

Vol.8, No.1, pp.53-76, January 2020

Published by ECRTD-UK

Print ISSN: 2053-5821(Print), Online ISSN: 2053-583X (Online)

Cassar, G. (2004). The financing of business start-ups. Journal of Business Venturing, 19(2), 261-283. Retrieved from http://bit.ly/33trHqZ

Cheng, R., and Rabena, J. (2017). Breaking borders: A case study on the impact of the foreign investments Act of 1991 on the Philippine economy. Retrieved from http://bit.ly/2yUVtqA

De Vera, I. J. M. (2012). An assessment of micro, small, and medium enterprises that underwent UP ISSI's Integrated Plant Surveys for the Periode 2006 to 2011. Procedia Economics and Finance, 4, 350-364. Retrieved from http://bit.ly/31xHGm4

Glick, R., Guo, X., \& Hutchison, M. (2006). Currency crises, capital-account liberalization, and selection bias. The Review of Economics and Statistics, 88(4), 698-714. Retrieved from http://bit.ly/36kt0IT

Hastings, J. S., Madrian, B. C., \& Skimmyhorn, W. L. (2013). Financial literacy, financial education, and economic outcomes. Annu. Rev. Econ., 5(1), 347-373. Retrieved from http://bit.ly/2REhqmI

Hughes, S., and Haworth, N. (2013). International Labour Organization (ILO): Coming in from the Cold. Routledge. Retrieved from http://bit.ly/2GoIqRL

Khor, N., Sebastian, I., and Aldaba, R. M. (2013). Enterprises in the Philippines: Dynamism and constraints to employment growth. Asian Development Bank Economics Working Paper Series, (334). Retrieved from http://bit.ly/2TqNGtX

Kimunguyi, S., Memba, F., and Njeru, A. (2015). Effect of budgetary process on financial performance of NGOs in health sector in Kenya. International Journal of Business and Social Science, 6 (12), 163-172. Retrieved from http://bit.ly/2ySzLDz

Kirman, A. (2010). Complex economics: Individual and collective rationality. Routledge. Retrieved from http://bit.ly/2TQSzyA

Plakalović, N. (2015). Financial literacy of SMEs managers. Managing intellectual capital and innovation for sustainable and inclusive society. Management, Knowledge, and Learning Joint International Conference. Retrieved from https://bit.ly/38yMo6E

Lanzona, L. A. (2015). Social enterprises and employment: Mainstreaming SMEs and employment creation (No. 2015-38). PIDS Discussion Paper Series. Retrieved from http://bit.ly/2YNeXgk

Lusardi, A., Mitchell, O. S., \& Curto, V. (2010). Financial literacy among the young. Journal of Consumer Affairs, 44(2), 358-380. Retrieved from http://bit.ly/30L6sjk

Mendoza, R. U., Canare, T. A., and Ang, A. P. (2015). Doing business: A review of literature and its role in APEC 2015 (No. 2015-37). PIDS Discussion Paper Series. Retrieved from http://bit.ly/2NQR9QY

Mohamed, A.I., and Ali, A.Y.S. (2013). Relationship between budgeting and performance of remittance companies in Somalia. Educational Research International, 2 (1), 106-115. Retrieved from http://bit.ly/2YUEUpi

Nunoo, J., \& Andoh, F. K. (2011). Sustaining small and medium enterprises through financial service utilization: Does financial literacy matter? (No. 323-2016-11592). Retrieved from https://bit.ly/2TSYJhN.

Ross, S. F., and Szymanski, S. (2010). Antitrust and inefficient joint ventures: Why sports leagues should look more like McDonald's and less like the United Nations. In The Comparative Economics of Sport (pp. 87-138). Palgrave Macmillan, London. Retrieved from http://bit.ly/2TRzfBy

Stern, J. M., Stewart III, G. B., \& Chew, D. H. (1995). The EVA® financial management system. Journal of Applied Corporate Finance, 8(2), 32-46. Retrieved from http://bit.ly/2NTuDXC

Terziovski, M. (2010). Innovation practice and its performance implications in small and medium enterprises (SMEs) in the manufacturing sector: A resource-based view. Strategic Management Journal, 31(8), 892-902. Retrieved from http://bit.ly/2H2rlhc 
International Journal of Small Business and Entrepreneurship Research

Vol.8, No.1, pp.53-76, January 2020

Published by ECRTD-UK

Print ISSN: 2053-5821(Print), Online ISSN: 2053-583X (Online)

Wagithunu, N. M., Muthee, J., and Thinguri, R. (2014). A Critical analysis of school principals' competence in financial management in Kenya: Accountability in educational planning and management. Journal of Education and Practice, 5(25), 103-107. Retrieved from http://bit.ly/38z8s0N

Warue, B. N., and Wanjira, T. V. (2013). Assessing budgeting process in small and medium enterprises in Nairobi's central business district: A case of hospitality industry. International journal of information technology and business management, 17(1), 1-11. Retrieved from http://bit.ly/31xQeta

Wild, T. (2017). Best practice in inventory management. Routledge. Retrieved from http://bit.ly/2Ky1AYF

Williams, J. R., Haka, S. F., Bettner, M. S., and Carcello, J. V. (2005). Financial and managerial accounting. China Machine Press. Retrieved from http://bit.ly/2N3sBV8 